
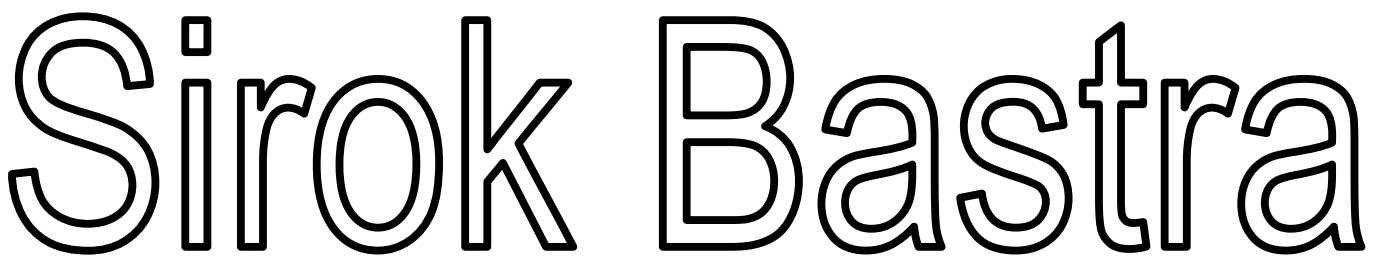

JURNAL ILMIAH KEBAHASAAN DAN KESASTRAAN

\begin{tabular}{|c|c|c|c|c|c|}
\hline $\begin{array}{c}\text { Sirok Bastra } \\
\text { Jurnal Kebahasaan dan } \\
\text { Kesastraan }\end{array}$ & Volume 2 & Nomor 2 & $\begin{array}{c}\text { Hlm. } \\
121-210\end{array}$ & $\begin{array}{l}\text { Pangkalpinang, } \\
\text { Desember 2014 }\end{array}$ & $\begin{array}{c}\text { ISSN } \\
2354-7200\end{array}$ \\
\hline
\end{tabular}

KANTOR BAHASA PROVINSI BANGKA BELITUNG 


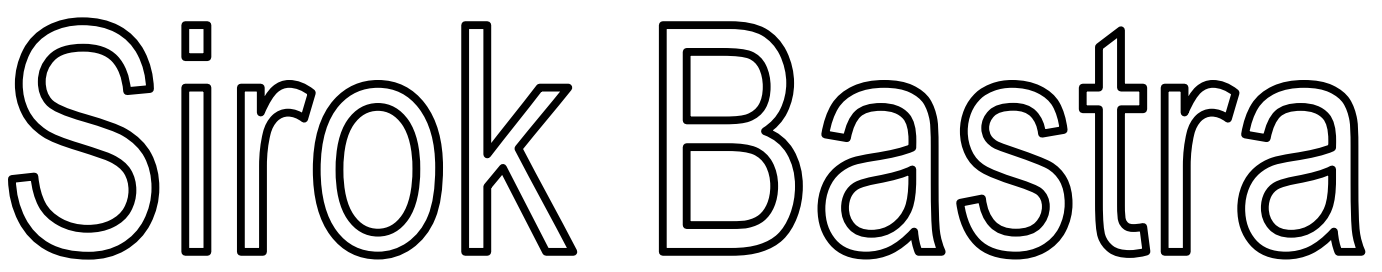

JURNAL ILMIAH KEBAHASAAN DAN KESASTRAAN

Jurnal ini merupakan wadah informasi mengenai kebahasan, kesastraan, dan pengajarannya yang memuat hasil penelitian, studi kepustakaan, dan tulisan ilmiah bidang kebahasan dan kesastraan serta pengajarannya. Sirok Bastra terbit dua kali setahun, yakni Juni dan Desember, serta terbit sejak Juni 2013.

\section{Penanggung Jawab}

Kepala Kantor Bahasa Provinsi Bangka Belitung Drs. Umar Solikhan, M.Hum.

Mitra Bestari

Prof. Dr. Agus Nuryatin, M.Hum. (Bidang Sastra dan Pengajarannya)

Prof. Amrin Saragih, Ph.D., M.A. (Bidang Bahasa dan Pengajarannya)

Dr. Felicia Nuradi Utorodewo, M.Hum. (Bidang Bahasa dan Pengajarannya)

Dr. Pujiharto, M.Hum. (Bidang Sastra dan Pengajarannya)

\section{Pemimpin Redaksi}

Rahmat Muhidin, S.S.

\section{Penyunting}

Prima Hariyanto, S.Hum.

\section{Perancang Sampul}

Feri Pristiawan, S.S.

\section{Kesekretariatan}

Khaliffitriansyah, S.Pd.

Dea Letriana Cesaria, S.Hum.

Lia Aprilina, S.Pd.

Andrian Priyatno, A.Md.

Elzam

\section{Alamat Redaksi dan Penerbit}

Kantor Bahasa Provinsi Bangka Belitung

Ruko Permata 7, Jalan Solihin G.P. Km 4, Kota Pangkalpinang, Prov. Kepulauan Bangka Belitung

Telp./Faks.: 0717-438455, Pos-el: sirokbastra@gmail.com, sirokbastra@kemdikbud.go.id

Pemuatan suatu tulisan dalam jurnal ini tidak berarti redaksi menyetujui isi tulisan tersebut. Isi tulisan menjadi tanggung jawab penulis. Tulisan telah ditinjau dan diulas oleh mitra bestari. Setiap karangan dalam jurnal ini dapat diperbanyak setelah mendapat izin tertulis dari penulis, redaksi, dan penerbit. 


\section{PENGANTAR}

Puji syukur ke hadirat Pemilik dan Pencipta semesta ini yang memiliki kuasa atas diri-Nya sendiri. Dialah Tuhan Yang Maha Esa yang telah memberikan rahmat dan hidayah-Nya sehingga Volume 2 Nomor 2 Jurnal Sirok Bastra Tahun 2014 dapat terbit tepat pada waktunya.

Pada edisi ini, dimuat sepuluh tulisan, yakni satu tulisan kebahasaan, satu tulisan pengajaran bahasa, dan delapan tulisan kesastraan. Dalam penelitiannya, Anitawati Bachtiar, Adek Dwi Oktaviantina, dan Rukmini membahas penggunaan alih kode dan campur kode pada dialog ubrug. Berdasarkan penelitian, ditemukan bentuk alih kode intern, berupa peralihan dari bahasa Jawa Serang menjadi Sunda Banten dan sebaliknya, serta alih kode metaforis dan situasional. Terdapat pula campur kode ke dalam yang berbentuk penyisipan kata pada kalimat yang diucapkan para pemain. Tujuan penggunaan alih kode dan campur kode itu adalah untuk memecah kekakuan saat pementasan, serta membangkitkan rasa humor agar penonton dapat terhibur.

Abdul Aziz melakukan penelitian yang bertujuan untuk mengupayakan peningkatan keterampilan siswa dalam menulis paragraf melalui metode inkuiri dengan menggunakan media audio pada siswa kelas $\mathrm{X}_{1}$ SMA DDI Alliritengae, Kabupaten Maros. Hasil penelitian menunjukkan bahwa metode inkuiri dengan menggunakan media audio dapat meningkatkan kemampuan menulis paragraf siswa kelas $\mathrm{X}_{1}$ SMA DDI Alliritengae, Kabupaten Maros pada tahap pelaksanaan dan tahap penilaian.

Dalam kajiannya, Tri Lia memaparkan nilai sosial dan budaya dalam cerita pendek "Sri Sumarah" karya Umar Kayam. Berdasarkan analisis, ditemukan beberapa nilai sosial budaya yang terdapat dalam cerita pendek ini, yaitu wayang dan stratifikasi sosial, masyarakat Jawa yang nrimo, sistem sapaan dalam masyarakat Jawa, mistik kejawen, masyarakat Jawa yang pembalas budi, keselarasan hidup masyarakat Jawa, dan latar politik PKI.

Dalam kajiannya, Dindin Samsudin membandingkan teka-teki (pertanyaan tradisional) yang terdapat di Provinsi Nanggroe Aceh Darussalam, yakni hiem dan yang terdapat di Provinsi Jawa Barat, yakni tatarucingan. Berdasarkan penelitian, terdapat beberapa hiem Aceh dan tatarucingan Sunda yang memiliki persamaan.

Dalam kajiannya, Kurniati membahas novel Orang-Orang Proyek karya Ahmad Tohari yang menurutnya berusaha menghadirkan sebuah realitas kemanusiaan, yakni melawan korupsi dan berbagai penyimpangan. Penulis menunjukkan bahwa di dalam novel tersebut terdapat kebenaran sosial. Karya ini memiliki sebab dan hasil kehebatan nilai artistik sebuah karya sastra (dengan dokumen sosialnya) sebagai potret kenyataan sosial.

Dalam penelitiannya, Sony Sukmawan membahas apokaliptisme sastra lisan Lereng Arjuna. Ciri-ciri yang terdapat dalam sastra lisan Lereng Arjuna dalam wujud (i) pemahlawanan tokoh mitologis dan sosok cikal bakal, trindih ukir, atau babat alas desa setempat; (ii) implikasi gagasan apokaliptik di balik latar penamaan desa, latar penamaan situs-situs purbakala, dan situs keramat alami; (iii) penamaan para-baureksa dalam mantra; serta (iv) pengungkapan apokaliptik sebagai pemulihan stabilitas alam melalui tindakan pencegahan yang persuasif.

Hestiyana membahas tema dan amanat cerita rakyat di Kecamatan Karang Intan, Kabupaten Banjar. Dalam penelitiannya, ditemukan tiga bentuk cerita rakyat, yaitu dongeng, legenda, dan mite. Cerita rakyat tersebut terdiri atas satu dongeng yang berjudul "Ular Tadung di Gunung Kiyau"; dua legenda berjudul "Asal Usul Nama Desa Karang Intan" dan "Asal Usul Nama Danau Purun"; dan satu mite berjudul "Pamandian Putri di Gunung Putra Bulu".

Dalam penelitiannya, Helmina Kastanya membahas tradisi lisan tatabuang manare dan badendang yang merupakan salah satu kekayaan sastra yang mengandung nilai estetika dalam pesta pernikahan masyarakat Pulau Ambon. Berdasarkan penelitian, bentuk tradisi lisan tatabuang manare dan badendang adalah prosesi berbalas pantun sambil menari diiringi alunan musik totobuang dan tifa. Tradisi ini berfungsi sebagai media penyatuan dua keluarga yang baru menjadi besan. Adapun nilai yang terkandung di dalamnya adalah nilai percintaan, kekeluargaan, dan sosial.

Dalam penelitiannya, Bagus Kurniawan membahas strategi pembacaan dekonstruksi karakter Arjuna sebagai lelananging jagad dalam lakon-lakon wayang purwa. Menurutnya, pemaknaan terhadap wayang masa kini mulai beragam, tidak hanya melalui dikotomi hitam-putih, tetapi juga melalui berbagai tafsir yang kemudian 
mendekonstruksi makna yang sudah mapan. Dalam tulisan ini, diuraikan strategi pembacaan secara dekonstruksi terhadap karakter Arjuna dengan menggunakan beberapa lakon wayang berbahasa Indonesia yang diterbitkan di majalah Cempala.

Mulawati mengkaji nilai karakter bangsa dalam nyanyian rakyat Muna di Provinsi Sulawesi Tenggara. Berdasarkan penelitian, unsur intrinsik nyanyian rakyat Muna menyiratkan nilai-nilai karakter bangsa seperti disiplin, selalu bekerja keras, mandiri, kreatif, dan toleransi.

Kami mengucapkan terima kasih kepada para penulis yang telah bersedia menerbitkan karya mereka pada edisi ini. Para penulis merupakan peneliti, pakar, dosen, guru, dan mahasiswa dari berbagai sekolah, perguruan tinggi, dan instansi. Terima kasih juga kami sampaikan kepada para mitra bestari yang telah memberi ulasan terhadap tulisan-tulisan yang masuk ke redaksi.

Demi memenuhi keberagaman isi dan penulis, Sirok Bastra membuka kesempatan bagi para peneliti dan penulis untuk menyampaikan hasil penelitian dan pemikiran mutakhir dalam bidang kebahasaan, kesastraan, dan pengajarannya.

Pangkalpinang, Desember 2014

\section{Tim Redaksi}




\section{UCAPAN TERIMA KASIH UNTUK MITRA BESTARI}

Redaksi Sirok Bastra mengucapkan terima kasih kepada para mitra bestari yang telah meninjau, menimbang, dan mengulas makalah-makalah yang diterbitkan dalam Sirok Bastra Volume 2 Nomor 2, edisi Desember 2014, yakni

\section{Prof. Dr. Agus Nuryatin, M.Hum.}

Bidang Sastra dan Pengajarannya

Universitas Negeri Semarang

Semarang, Jawa Tengah

Prof. Amrin Saragih, Ph.D., M.A.

Bidang Bahasa dan Pengajarannya

Universitas Negeri Medan

Medan, Sumatra Utara

\section{Dr. Felicia Nuradi Utorodewo, M.Hum.}

Bidang Bahasa dan Pengajarannya

Universitas Indonesia

Depok, Jawa Barat

\section{Dr. Pujiharto, M.Hum.}

Bidang Sastra dan Pengajarannya

Universitas Gadjah Mada

Yogyakarta, Daerah Istimewa Yogyakarta 


\section{DAFTAR ISI}

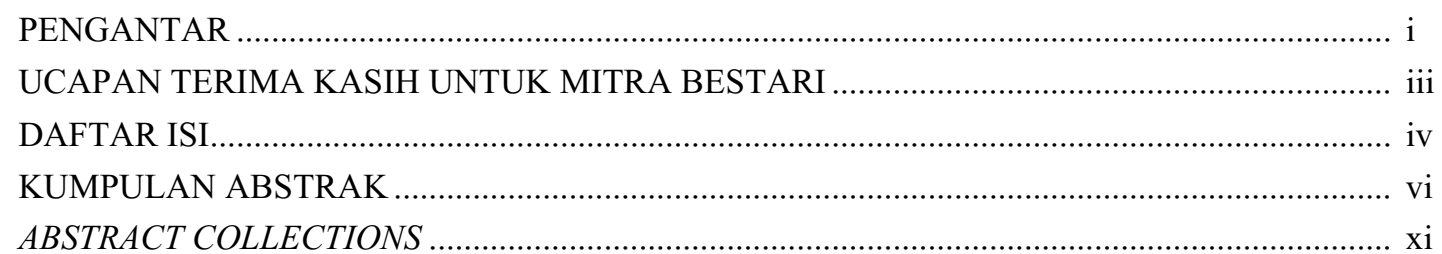

\section{UBRUG: KAJIAN SOSIOLINGUISTIK}

(Ubrug: Sociolinguistic Study)

Anitawati Bachtiar, Adek Dwi Oktaviantina, dan Rukmini $121-128$

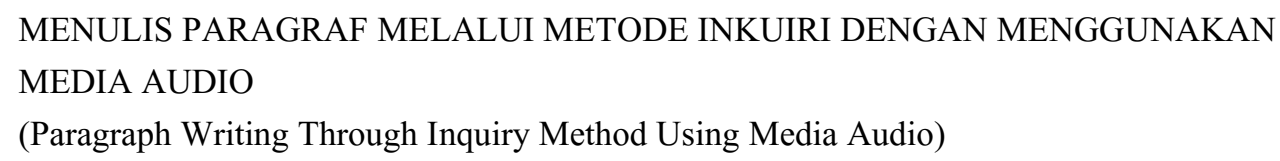

TEMA DAN AMANAT CERITA RAKYAT DI KECAMATAN KARANG INTAN, KABUPATEN BANJAR

(Theme and Message of Folklore in Karang Intan Subdistrict, Banjar Regency)

TATABUANG MANARE DAN BADENDANG DALAM PESTA PERNIKAHAN MASYARAKAT PULAU AMBON

(Tatabuang Manare and Badendang in Wedding Party of Ambon Island Society) 
MENGGUGAT ARJUNA SEBAGAI LELANANGING JAGAD: SEBUAH STRATEGI PEMBACAAN DEKONSTRUKSI KARAKTER ARJUNA DALAM LAKON-LAKON WAYANG PURWA

(Arjuna Sued as A Man of Universe: The Deconstruction of Reading Strategy for Arjuna's Character on Purwa Puppet Shows)

Bagus Kurniawan $193-200$

NILAI KARAKTER BANGSA DALAM NYANYIAN RAKYAT MUNA

(Nation Character Values in Munanese Folksong)

Mulawati $201-201$ 
Kurniati : Korupsi yang Menggurita: Tinjauan Sosiologi Sastra Orang-Orang Proyek

\title{
KORUPSI YANG MENGGURITA: TINJAUAN SOSIOLOGI SASTRA TERHADAP NOVEL ORANG- ORANG PROYEK
}

\author{
Excessive Corruption: Literature Sociology Study in Novel Orang-Orang Proyek \\ Kurniati \\ SMK Negeri 1 Sungailiat \\ Jalan Singayudha 1, Sungailiat, Bangka \\ Pos-el: kurnia_inka@yahoo.com
}

(diterima 29 Juni 2014, disetujui 3 November 2014, revisi terakhir 27 November 2014)

\begin{abstract}
Abstrak
Sebagai bacaan yang menghibur, karya sastra merupakan media kontrol dalam dimensi fiksi karena karya sastra lahir dari realitas objektif dan diangkat dengan imajinasi-realitas menjadi realitas baru. Sastra juga menjadi sarana atau media diskusi yang dapat mengantarkan penciptaan ruang perubahan sosial, salah satunya dengan kegiatan mengkaji karya sastra. Karena sastra juga menjadi bahan baku pembelajaran di sekolah, sastra wajib diapresiasi dengan cara dikaji/analisis kebermaknaannya. Melalui metode deskriptif dengan pendekatan objektif (sosiologi sastra) sebuah karya sastra dapat dikaji. Novel Orang-Orang Proyek menjadi karya yang berusaha menghadirkan sebuah realitas kemanusiaan, yakni melawan korupsi dan berbagai penyimpangan. Orang-Orang Proyek tidak hanya mewakili zamannya (saat ditulis dan diterbitkan), tetapi juga mewakili kekinian. Di dalamnya terdapat kebenaran sosial. Karya tersebut memiliki sebab dan hasil kehebatan nilai artistik sebuah karya sastra (dengan dokumen sosialnya) sebagai potret kenyataan sosial. Inilah yang menjadikan Orang-Orang Proyek sebagai sastra yang bermakna.
\end{abstract}

Kata kunci: sosiologi sastra, Orang-Orang Proyek, korupsi

\begin{abstract}
As entertaining reading, literary work is control media in fiction dimension since literary work was born from objective reality and raised by reality-imagination to the new reality. Literature becomes tools or discussion media conveying the creation of social exchange room, one other thing is the activity of examining literary work. Since literature also becomes basic material of studying at school, it compulsorily appreciated by examining/analysing the meaning. By way of descriptive method and objective approach (sociology of letters) a literary work can be examined. Novel Orang-Orang Proyek becomes a work which is attempting to represent a human reality, i.e. fighting for corruption and various deviations. Orang-Orang Proyek not only represents its age (written and published), but also representing nowadays. It has social truth inside. The literary work has caused and effect of the artistic value grandeur in a literary work (with it social document) as social fact portrait. It makes Orang-Orang Proyek as meaningful literature.
\end{abstract}

Keywords: sociology of letters, Orang-Orang Proyek, corruption

\section{PENDAHULUAN}

\subsection{LatarBelakang}

Karya sastra yang baik adalah karya yang mampu mengarahkan dan mendidik para pembaca karena nilai-nilai kebenaran yang terkandung di dalamnya. Di balik fungsinya sebagai bacaan yang menghibur, karya sastra merupakan media kontrol dalam dimensi fiksi. Hal ini disebabkan karya sastra lahir dari realitas objektif yang diangkat oleh pengarangnya dengan imajinasi-realitas menjadi realitas baru.
Bahan imajinasi yang diangkat oleh pengarang bukanlah lamunan, fantasi, atau khayalan, melainkan fakta kehidupan yang telah mengkristal dalam diri pengarang. Fakta kehidupan tampak pada pengalaman diri, pengalaman batin, pengalaman bahasa, maupun pengalaman estetis pengarang (Tjahyono, 1988:37)

Menurut Wellek (1989:25) sebuah sastra yang bermutu ditunjukkan dengan kandungan prinsip dulce et utile (indah dan berguna). Artinya karya sastra 
yang bermutu harus mampu memenuhi syarat sebagai karya seni yang estetis (keindahan yang tinggi) dan bermanfaat bagi pembacanya. Setelah membaca karya sastra ada sejumlah nilai-nilai kehidupan yang diperoleh oleh pembaca. Setidaknya karya sastra itu mampu membuat pembaca merenung dan menyentuh rasa kepekaan hati berkaitan dengan kehidupan sosial pembaca.

Berkenaan dengan fungsi, Mulyani (1999:92-93) menyebutkan lima fungsi sastra, yakni (1) fungsi rekreatif: memberikan hiburan yang menyenangkan bagi penikmatnya; (2) fungsi dedaktif: mampu mengarahkan pembacanya pada nilai-nilai yang terkandung dalam sastra; (3) fungsi estetis: mampu memberikan keindahan karena nilai sastra dan sifat keindahannya; (4) fungsi moralitas: mampu memberikan ilmu pengetahuan kepada pembacanya pada aspek moralitas, dalam hal ini sebagai fungsi kontrol; dan (5) fungsi religius: mampu menghadirkan nuansa nilai-nilai ketuhanan.

Dengan demikian, sastra dapat memberikan gambaran terhadap nilai hidup suatu masyarakat yang bersifat pribadi, bahkan dalam tatanan suatu wilayah nation state (negara bangsa). Menyorot kehidupan yang secara tidak langsung menggambarkan jiwa dan karakter suatu masyarakat, karya sastra seperti ini menginginkan gerakan kebudayaan baru yang lebih baik. Penciptaan karya sastra yang kritis transformatif diharapkan hadir dalam lingkaran budaya yang dirasakan semakin tidak jelas.

Gerakan kebudayaan yang mengharapkan adanya perubahan tentunya harus bersifat kritis, jujur, terbuka sekaligus menawarkan ide-ide cerah yang tegas walaupun kadang bernuansa perlawanan untuk mengungkap fakta kemanusiaan yang bernilai penting. Suhairi dalam kumpulan Karya Sastra (2009:82) menulis "Dalam ruang yang lebih khusus, gerakan kebudayaan juga menjadi media untuk menuturkan kembali berbagai peristiwa aktual dengan tujuan menciptakan ruang diskusi bagi perubahan sosial."

Pengkajian karya sastra dapat digunakan sebagai sarana atau media diskusi yang dapat mengantarkan penciptaan ruang bagi perubahan sosial. Sastra dengan segala kelebihan dan keterbatasannyadengan fungsi dedaktif, estetis, dan moralitasnyatelah mencerminkan fakta kemanusiaan kita. Selain itu, sastra juga mampu memberikan ilmu pengetahuan kepada pembacanya pada aspek moralitas; dalam hal ini, sebagai fungsi kontrol.

Salah satu karya sastra yang mencerminkan dan memberikan pengetahuan moralitas pada pembacanya adalah Orang-Orang Proyek karya Ahmad Tohari. Karya ini telah lama ditulis (pada masa Orde Baru), tetapi konteks kenikian pada novel tersebut dapat menjadi pembelajaran berharga jika benar-benar dicermati.

\subsection{Tujuan}

Tulisan ini bertujuan untuk memberikan makna pada karya Orang-Orang Proyek sebagai perwujudan atau konkretisasi sastra sesuai dengan fungsinya. Dengan pemaknaan terhadap karya sastra melalui pengkajian sosiologi sastra, dapat diketahui kehidupan sosial budaya masyarakat, suku bangsa, atau suatu bangsa.

\subsection{Manfaat}

Kajian ini dapat dijadikan bahan pembelajaran sastra di sekolah pada mata pelajaran bahasa dan sastra Indonesia. Selain itu, kajian ini bermanfaat untuk pemaknaan sastra, apresiasi, dan sebagai cermin kehidupan masyarakat.

Selain sebagai bahan pembelajaran untuk dunia pendidikan, kajian ini juga bermanfaat bagi para sastrawan agar dapat mengembangkan karya-karya mereka selanjutnya.

\subsection{Metode}

Kajian ini menggunakan metode deskriptif kualitatif dengan orientasi analisis menggunakan pendekatan kritik mimetik (memandang karya sastra sebagai tiruan, cerminan, representasi alam maupun kehidupan) berdasarkan teori Abrams melalui pendekatan objektif.

Pendekatan ini disebut juga dengan sosiologi sastra yang memandang karya sastra sebagai dokumen sosial atau gambaran kehidupan masyarakat, atau psikologi sastra yang memandang karya sastra sebagai dokumen. Tulisan ini menguraikan bagaimana memandang karya sastra sebagai bentuk persepsi pengarang terhadap realitas kehidupan sosial suatu zaman sehingga pemahaman sastra dapat berarti. 


\section{KERANGKA TEORI}

\subsection{Kajian Prosa Fiksi}

Untuk mengetahui sastra yang dapat memberikan gambaran terhadap nilai kehidupan suatu masyarakat yang bersifat pribadi, bahkan dalam tatanan suatu wilayah nation state (negara bangsa), kita dapat melakukan pengkajian terhadap sastra dengan berbagai pendekatan. Melalui berbagai pendekatan, kita dapat menyorot kehidupan yang secara tidak langsung menggambarkan jiwa dan karakter suatu masyarakat.

Berdasarkan pendekatan terhadap karya sastra, kritik sastra dapat digolongkan ke dalam empat tipe (Abrams dalam Prodopo, 2007:192), yaitu apakah dalam menerangkan atau menimbang karya sastra, kritik sastra menghubungkan karya sastra dengan dunia luar, dengan pembaca, dengan pengarang, atau pun yang menganggap karya sastra sebagai keseluruhan yang berdiri sendiri.

\subsubsection{Kritik Mimetik (Mimetic Criticism)}

Kritik mimetik memandang karya sastra sebagai tiruan, pencerminan atau penggambaran dunia luar, dan kehidupan manusia. Kriteria utama yang dikenakan pada karya sastra adalah "kebenaran" penggambarannya terhadap objek yang digambarkan atau yang hendaknya digambarkan.

Pandangan itu telah berkembang jauh sehingga muncullah sosiologi sastra yang memandang karya sastra sebagai dokumen sosial atau gambaran kehidupan masyarakat. Selain itu, dapat pula memunculkan psikologi sastra yang memandang karya sastra sebagai dokumen dunia batin masyarakat sebagaimana terwujud dalam dunia batin pengarang dan tokoh-tokoh ciptaannya (Yudiono, 2009:42). Dengan demikian pandangan tersebut menyatakan bahwa karya sastra merupakan bentuk persepsi pengarang terhadap realitas kehidupan sosial suatu zaman sehingga pemahaman sastra berarti pengkajian hubungan antara karya sastra dengan dunia ideologis yang berkembang di masyarakat dan zamannya.

\subsubsection{Kritik Pragmatik (Pragmatic Cristicism)}

Pendekatan yang memandang karya sastra sebagai sesuatu yang disusun untuk mencapai efek-efek tertentu pada audience (pembaca) - yaitu efek-efek seperti kesenangan, estetik, pendidikan atau jenis- jenis perasaan - cenderung menimbang nilai karya sastra sesuai dengan keberhasilannya dalam mencapai tujuan tersebut.

\subsubsection{Kritik Ekspresif}

Pendekatan ini, terutama, menghubungkan karya sastra dengan pengarang. Kritik ini mendefinisikan puisi sebagai ekspresi atau curahan, atau perasaan, sebagai produk imajinasi pengarang yang beroperasi (bekerja) dengan pikiran-pikiran, perasaan. Yudiono (2009:43) menyatakan bahwa melalui pendekatan ini, penilaian sastra tertuju pada emosi atau keadan jiwa pengarang sehingga karya sastra merupakan sarana atau alat untuk memahami keadaan jiwa pengarang.

\subsubsection{Pendekatan Objektif}

Pendekatan ini memandang karya sastra sebagai dunia otonom yang dapat dilepaskan dari dunia pengarang dan latar belakang sosial budaya zamannya sehingga karya sastra dapat dianalisis berdasarkan strukturnya sendiri. Dengan kata lain karya sastra dipahami berdasarkan unsur intrinsiknya.

Pendekatan-pendekatan ini merupakan pijakan dasar yang menentukan sikap kritikus dalam pemilihan teori, penerapan metode, dan penilaiannya. Misalnya apabila karya sastra dipandang sebagai cermin atau gambaran kehidupan suatu masyarakat pada masa atau zaman tertentu, kritiknya dapat memanfaatkan sosiologi atau histografi dengan segala kerumitannya dan penilaiannya pun seharusnya relevan dengan kepentingan sosial.

Akan tetapi, pada kenyataannya, sebuah kritik sastra jarang hanya menggunakan satu pendekatan secara mutlak. Keempat pendekatan itu sering digunakan, bahkan kritik sastra hendaknya memerhatikan keempat pendekatan tersebut demi kesempurnaan/ketepatannya dalam menimbang karya sastra (Prodopo, 2007:193). Dipertegas lagi oleh Teeuw (dalam Yudiono, 2009:44) bahwa keempat pendekatan tersebut saling melengkapi dan saling memerlukan sehingga tidak hanya satu pendekatan yang terbaik. Adapun dalam penerapannya bergantung pada sifat karya sastra tertentu. Demikian pula dalam pengkajian terhadap novel Orang-Orang Proyek karya Ahmad Tohari. 
Kurniati : Korupsi yang Menggurita: Tinjauan Sosiologi Sastra Orang-Orang Proyek

\subsection{Sosiologi Sastra}

\subsubsection{Pengertian Sosiologi Sastra}

Sosiologi sastra merupakan cabang penelitian sastra yang bersifat reflektif, yang tidak memandang sastra dalam kekosongan makna. Sosiologi sastra memandang karya sastra sebagai dokumen sosial atau gambaran kehidupan masyarakat. Selain itu, dapat pula memunculkan psikologi sastra yang memandang karya sastra sebagai dokumen dunia batin masyarakat sebagaimana terwujud dalam dunia batin pengarang dan tokoh-tokoh ciptaannya (Yudiono, 2009:42). Dengan demikian, pandangan tersebut menyatakan bahwa karya sastra merupakan bentuk persepsi pengarang terhadap realitas kehidupan sosial suatu zaman sehingga pemahaman sastra berarti pengkajian hubungan antara karya sastra dengan dunia ideologis yang berkembang di masyarakat dan zamannya. Konsep penelitian sosiologi sastra adalah memandang karya sebagai cermin (mirror), sebagai tiruan (mimesis) masyarakat, atau sebagai manifestasi peristiwa sejarah sejarah dan keadaan sosial budaya (Endraswara, 2008:78).

\subsubsection{Sasaran Penelitian Sosiologi Sastra}

Kajian sosiologi sastra dapat diteliti setidaknya melalui tiga perspsektif. Pertama, perspektif teks sastra yaitu peneliti menganalisis karya sebagai buah refleksi kehidupan masyarakat dan sebaliknya. Teks biasanya dikelompokkan dan dijelaskan makna sosiologisnya. Kedua, perspsektif biografis yaitu peneliti menganalisis pengarang. Ketiga, perspektif reseptif yaitu peneliti menganalisis penerimaan masyarakat terhadap teks sastra.

Sementara itu, kajian sastra melalui penelitian sosiologi sastra akan menganalisis karya sastra berdasarkan hal-hal berikut.

1) Fungsi sosial sastra yang mempertanyakan seberapa jauh nilai sastra berkaitan dengan nilai sosial dan sampai seberapa jauh nilai sastra dipengaruhi oleh nilai sosial.

2) Produksi dan pemasaran sastra yang menyangkut penyebaran atau pengembangan karya sastra.

3) Sastra sebagai cermin masyarakat.

4) Konteks sosiobudaya, yaitu pendekatan yang mengungkap aspek sastra dengan refleksi dokumen sosiobudaya, mengimplikasikan bahwa karya sastra menyimpan hal-hal penting dalam kehidupan sosiobudaya (Endraswara, 2008:8795).

\section{HASIL DAN PEMBAHASAN}

Kajian sosiologi sastra dalam penelitian ini memandang karya sastra melalui perspsektif perspektif teks sastra yaitu peneliti menganalisisnya sebagai buah refleksi kehidupan masyarakat dan sebaliknya. Sementara itu, analisisnya tertuju pada sasaran fungsi sosial sastra (sebagai cerminan masyarakat) dan konteks sosiobudaya (terkait dengan sosiokultural masyarakat kita sekarang).

\subsection{Novel Orang-Orang Proyek Ahmad Tohari}

Dalam Ahmad Tohari: Karya dan Dunianya, Yudiono (2003) menyatakan bahwa kepengarangan Ahmad Tohari berangkat dari kesadaran yang kukuh untuk memanfaatkan karya sastra sebagai sarana pengingat masyarakat agar semakin beradab.

Novel Orang-Orang Proyek karya Ahmad Tohari mulanya terbit sebagai cerita bersambung di harian Suara Merdeka Semarang bulan Februari-April 2002 kemudian dibukukan oleh Penerbit Jendela di Yogyakarta. Selanjutnya, novel ini mengalami beberapa kali cetak ulang dengan penerbit yang berbeda. Novel yang terdiri dari lima bagian ini bertema sosial politik, yakni pertarungan antara idealisme dan pragmatisme, politisasi, serta korupsi dalam proyek-proyek pembangunan. Novel ini ditulis pada masa Orde Baru dan pernah diterbitkan pada masa itu juga. Novel tersebut juga diterbitkan kembali pasca-Reformasi. Orang-Orang Proyek bercerita tentang proses pembangunan sebuah jembatan dengan berbagai masalah yang melilit.

Seorang insinyur bernama Kabul dipercaya menjadi pelaksana sebuah proyek pembangunan jembatan di Sungai Cibawor. Ia bekerja sama dengan pimpinan proyek (Dalkijo) yang terbiasa "bermain" dalam kongkalikong proyek. Sekian lama berada di camp proyek, Kabul mulai merasakan ketidakberesan dalam penanganan bahan material dan ricuh soal dana anggaran. Kabul mengalami konflik batin. Selain dia, ada juga seorang teman yang menjadi staf desa yang juga merasakan hal yang sama dengannya. Mereka merasakan perjuangan semasa kuliah dulu yang selalu kritis dan kini tak ada artinya lagi melawan arus politik uang yang menganak dan mengakar hingga ke 
pinggir desa. Demi kegiatan politik, proyek harus segera diselesaikan dengan konsekuensi kondisi bangunan jembatan jelek. Proyek dijadikan ajang kampanye dalam rangka pemilu tahun 1992 bagi penguasa daerah kala itu.

Kabul akhirnya memilih berhenti menjadi pelaksana proyek walaupun pembangunan jembatan belum rampung. Ia tak sanggup menanggung risiko dengan prediksi yang akan terjadi.

\subsection{Sosiologi Sastra (Kajian Mimetik) Orang- Orang Proyek}

\subsubsection{Fungsi Sosial Sastra Orang-Orang Proyek}

Orang-Orang Proyek bercerita tentang sesuatu yang terjadi pada masa Orde Baru. Akan tetapi, fenomena yang diungkap dalam cerita ini masih relevan bahkan menjadi "terang benderang" dengan konteks kekinian. Salah satu contoh saja, tidak perlu dibahas lagi di sini bagaimana proyek pembangunan Wisma Altet di Jaka Baring, Sumatera Selatan yang menjadi kasus politik yang mengherankan. Pejabat negara banyak yang cuci tangan setelah mengorbankan segelintir bawahan.

Orang-Orang Proyek adalah sebuah dokumentasi sastra yang cukup menggambarkan suasana. Selain itu, secara cantik, novel ini berusaha menghadirkan sebuah realitas kemanusiaan, yakni melawan korupsi dan berbagai penyimpangan. Keterkaitan cerita pada masa kini, sangat dekat. Isu-isu ekonomi, sosial, budaya, dan agama bukan menjadi persoalan yang mesti dicarikan pemecahannya, melainkan menjadi hal yang menguntungkan untuk mendapat simpati rakyat atas sekadar pernyataan-pernyataan heroik.

\subsubsection{Orang-Orang Proyek sebagai Cermin Masyarakat}

Kisah Orang-Orang Proyek dalam gambaran kehidupan masa kini seperti isu-isu ekonomi, sosial, budaya, dan agama telah menjadi persoalan yang mesti dicarikan pemecahannya. Membaca Ahmad Tohari dengan karyanya ini, laksana becermin dengan kehidupan kini. Kepentingan politik yang dikaitkan dengan pencitraan seseorang dan golongan semakin terang pada era sekarang. Persoalan rakyat yang lebih membutuhkan perhatian seakan ditepiskan karena persoalan kelangsungan legitimasi kekuasaan lebih diutamakan. Penyelesaian kasus-kasus yang menjerat pejabat negara tak pernah tuntas dan selalu bias. Rakyat menjerit karena berbagai isu di bidang ekonomi dan konflik sosial yang acap kali terjadi, seadangkan solusi pemecahannya hanya sekadar menjadi wacana yang lantang diopinikan dalam peta politik negara.

Sejumlah realitas itu telah lama diangkat oleh Ahmad Tohari dengan bahasanya yang lugas dalam Orang-Orang Proyek.

Mungkin juga sikap pragmatis sebagian insinyur disebabkan meriahnya contoh dari atas. Keluarga presiden, menteri, jenderal, gubernur, anggota DPR, pengusaha yang kongkalikong dengan pejabat, hidup dalam pragmatisme yang sangat kental (Tohari, 2007:148).

Terkadang sikap sangat tega terhadap kelompok masyarakat miskin sering mereka perlihatkan tanpa "tedheng aling-aling". Korupsi dalam berbagai bentuk dan manifestasinya dibiarkan merajalela... (Tohari, 2007:149).

Sementara itu, pelaku politik yang menjadi penggerak republik ini selalu menderita penyakit lupa dengan segala permasalahan yang sudah menjadi tanggungannya untuk diselesaikan atau minimal dicarikan solusi yang tidak menyengsarakan rakyat. Sindiran Tohari mengenai kenyataan di atas, ditunjukkan dalam petikan berikut.

Atau karena daulat rakyat sesungguhnya memang belum tegak di republik ini. ... Dalam sistem kekuasaan seperti ini, presiden merasa dirinya raja. Dan birokrasi di bawahnya, dari pusat sampai ke daerah, merasa diri mereka adalah patih, adipati, panikel, penewu, dan seterusnya. Orang-orang politik yang berkumpul di gedung parlemen tak lebih dari orang yang dibayar sebagai tukang stempel kerajaan. Tentara tidak lagi membela rakyat dan tanah air tetapi pembela kekuasaan raja (Tohari, 2007:149).

Dalam hal praktik korupsi, Orang-Orang Proyek mengisahkan adanya masalah, yakni adanya permainan dan "bancakan" setiap kali proyek pembangunan dilaksanakan. Hal tersebut benar-benar telah menggurita dalam kehidupan bangsa ini. Yang paling naif adalah ketika proyek dilaksanakan hanya untuk kepentingan politik penguasa. Praktik korupsi tidak hanya terjadi di seputar kekuasaan, tetapi juga telah merambah ke ranah grassroot. 
Ahmad Tohari telah mampu menghadirkan kisah yang naturalistik. Ia menuangkan keadaan yang sebenarnya dengan menonjolkan aspek kebobrokan orang-orang proyek. Ahmad Tohari terlihat bersemangat dalam menuangkan kejadian yang dirasa dan dilihatnya, baik melalui kacamatanya maupun tiupan media. Oleh karena itu, ia menggunakan kalimat dan pilihan kata yang sinis serta menyindir. Ahmad Tohari menegaskan bahwa yang dikorbankan dalam hampir setiap pembangunan dan proyekproyek pembangunan adalah rakyat, padahal proyek seharusnya untuk rakyat, bukan proyek penguasa. Hal ini dapat dilihat dalam ilustrasi berikut.

Penguasa yang punya proyek dan para pemimpin politik lokal menghendaki jembatan itu selesai sebelum Pemilu 1992. Karena, saya kira, peresmiannya akan dimanfaatkan sebagai ajang kampanye partai golongan penguasa. Menyebalkan. Dan inilah akibat bila perhitungan teknis ilmiah dikalahkan oleh perhitungan politik." (Tohari, 2007:10).

Fenomena ini ternyata tidak hanya terjadi pada rezim kala itu seperti yang diceritakan dalam novel, bahkan pada era kepemimpinan sekarang pun masih terjadi. Setiap kebijakan pemerintah yang langsung bersentuhan dengan rakyat selalu saja diklaim oleh parpol penguasa sebagai keberhasilannya. Kehadiaran kata menyebalkan menunjukkan suasana tekanan emosional yang cukup kuat dan sinis. Bahkan sangat apatis. Hal ini terlihat dalam kutipan berikut.

Sedihnya lagi, tak sedikit insinyur telah kehilangan komitmen profesi dan tanggung jawab moral keilmuan mereka. Jadilah mereka bagian dalam barisan orang yang mengebiri ilmu teknik sipil. Akibatnya, bangunan sipil-jalan raya, SD Inpres, jembatan, gedung ini-itu, dan seterusnya berdiri dengan mutu di bawah standar. Dengan tingkatan mutu yang rendah, nilai manfaat bangunan itu pasti rendah pula-umurnya pendek, tingkat keamanan payah dan seterusnya (Tohari, 2007:68-69).

Kenyataan juga terjadi pada suatu hal yang dianggap sebagai kegiatan yang positif menjadi bermakna kurang etis dibicarakan, dan sekarang menjadi sebuah istilah yang menyakitkan bila di dengar.

Oh, adikku, kamu belum tahu betapa sulit menaati ketentuan ilmu teknik di proyek ini. Karena anggaran sudah jadi bancakan sehingga semua sektornya harus ditekan. Biro pengawas yang menjamin mutu proyek pun tidak kebal duit. Dan orang-orang DPRD? Ah, mereka tidak mau pusing apakah pasir atau besi beton memenuhi persyaratan teknik atau tidak. Bagi mereka yang penting bendaharawan proyek "tahu" bila mereka datang (Tohari, 2007:108).

Kata bancakan yang sering didengar oleh siapa pun benar-benar menjadi sumber inspirasi bagi Ahmad Tohari untuk menegaskan kembali bahwa hampir semua proyek pembangunan penuh dengan penyimpangan. Bancakan dapat berkonotasi negatif sebagai pengambilan sebagian manfaat terhadap apa pun untuk kepentingan sesaat bagi pribadi atau golongan dengan cara tidak etis dan cenderung merugikan pihak lain. Akibatnya, anggaran yang seharusnya dipatok sesuai RAB (Rencana Anggaran Biaya) terpaksa harus dipotong. Dampaknya, mutu pekerjaan tidak sesuai dengan bestek. Semua dapat menebak mutu kegiatan pembangunan yang dikerjakan. Inilah awal praktik korupsi dalam proyekproyek pembangunan.

Orang-Orang Proyek bercerita tentang pembangunan jembatan yang dibiayai dari pinjaman luar negeri. Proyek yang dibiayai dari pinjaman luar negeri ini juga tidak lepas dari berbagai penyimpangan internal orang-orang proyek dan di luar proyek. Kecermatan Ahmad Tohari mengungkap realitas dalam dunia proyek pembangunan ditandai dengan ekspresinya bahwa sejak awal (tahap perencanaan) proyek tersebut telah dicampuri hal-hal politik. Campur tangan banyak pihak, para politisi DPRD, militer, dan partai penguasa telah membuat beban rakyat bertambah. Watak para politisi dan pelaksana yang menganggap setiap proyek adalah proyeknya telah menyebabkan kebocoran di manamana. Hal ini tersirat dalam novel, seperti dalam petikan berikut.

Dan campur tangan itu tidak terbatas pada penentuan awal pekerjaan yang menyalahi rekomendasi para perancang, tapi masuk juga ke halhal lain. Proyek ini yang dibiayai dengan dana pinjaman luar negeri dan akan menjadi beban masyarakat, mereka anggap sebagai milik pribadi. Kabul tahu, bagaimana bendahara proyek wajib mengeluarkan dana untuk kegiatan partai golongan penguasa... Belum lagi dengan oknum sipil maupun 
militer, juga oknum-oknum anggota DPRD yang suka minta uang saku kepada bendahara proyek kalau mereka mau pelesir ke luar daearah (Tohari, 2007: 25-26).

Ditunjukkan pula oleh pengarang tentang "permainan" mulai dari lelang pekerjaan hingga waktu termin. Ia paham betul proses kontraktor mendapatkan proyek-proyek bangunan fisik maupun pengadaan barang. Para kontraktor dikatakan harus menjual idealismenya untuk "bermain” dengan panitia lelang atau dengan kontraktor lainnya untuk mendapatkan pekerjaan. Dan serentetan peristiwa suap-menyuap lainnya, mulai dari kontraktor sampai pimpinan proyek. Hal ini dilakukan agar pelaksana proyek dapat dengan lancar mengurus anggaran per termin sesuai hasil pekerjaannya.

"Yah, berapa kali harus saya katakan, seperti proyek yang kita kerjakan sebelum ini, semuanya selalu bermula dari permainan. Di tingkat lelang pekerjaan, kita harus bermain. Kalau tidak, kita tidak bakalan dapat proyek. Dan anggaran yang turunnya diatur per termin, baru kita peroleh bila kita tahu cara bermain. Kalau tidak, kita pun tak akan dapat uang meski sudah menang lelang...bila perlu kita jadi koboi (Tohari, 2007:27).

Orang-Orang Proyek juga mengisahkan bahwa penyimpangan proyek pembangunan jembatan juga merambah pada level massa, yakni orang-orang kampung, mandor proyek, kuli proyek, dan hampir semua orang yang punya akses pada proyek jembatan. Mereka berupaya mengambil manfaat dari proyek tersebut. Sebagai contoh, penduduk bekerja sama dengan kuli bangunan dan mandor proyek bermain dengan tukang supir truk. Hal ini dapat dilihat dalam petikan berikut.

Dan ternyata orang-orang kampung pun ikutikutan nakal. Bila mereka hanya minta ikut memakai kayu-kayu bekas atau meminjam generator cadangan untuk keperluan perhelatan masih wajar. Tapi kenakalan mereka bisa lebih jauh. Selain menyuap kuli untuk mendapatkan semen, paku atau kawat rancang, mereka juga sering meminta besi-besi potongan, kata mereka untuk membuat linggis.

Mandor yang mencatat penerimaan material pun pandai bermain. Dia bisa bermain dengan menambah angka jumlah pasir atau batu kali yang masuk. Truk yang masuk sepuluh kali bisa dicatat menjadi lima belas kali, dan untuk kecurangan itu dia menerima suap dari para sopir (Tohari, 2007: 26).

Korupsi pada proyek pembangunan jembatan, seperti yang dicontohkan oleh Ahmad Tohari, berlangsung sporadis dari berbagai arah, termasuk hal yang berkedok agama. Dengan alasan penyelesaian pembangunan tempat ibadah, mereka berusaha mendapatkan bagian anggaran dari proyek pembangunan jembatan. Panitia pembangunan masjid dengan memanfaatkan kekuasaan dan parpol penguasa mendatangi pelaksana proyek jembatan, yakni Kabul. Namun, secara diplomatis ditolak oleh Kabul seperti dalam kutipan berikut.

Karena kesuciannya, pembangunan sebuah masjid harus tertib dan pakai tata krama. Semua material di sini tidak boleh dipakai untuk tujuan lain, kecuali sisanya. Anggaran proyek ini sudah digerogoti di sana-sini hingga mengakibatkan kebocoran mencapai tiga puluh persen. Dan sekarang panitia pembangunan masjid mau ikut-ikutan membebani proyek ini. Terus terang saya khawatir hal ini menodai kecusian agama kita (Tohari, 2007:140).

Melalui kutipan tersebut pengarang hendak mengungkap fenomena yang sering terjadi di masyarakat kita, yakni kecelakaan logika atas tafsir agama. Apa pun alasannya atau asalnya apabila dimanfaatkan untuk kebaikan, apalagi untuk kepentingan agama, menjadi bernilai kebenaran.

\subsubsection{Konteks Sosiobudaya Orang-Orang Proyek}

Membaca novel Ahmad Tohari ini, pembaca diajak ikut berdiskusi tentang kondisi kebangsaan yang kemaruk dari berbagai aspek kehidupan. Bahkan sekarang bertambah saja keanehan permainan di "tingkat atas" kita. Baik dari aspek politik, ekonomi, sosial, keagamaan, bahkan budaya.

Dalam menyampaikan kritiknya, pengarang menggunakan tokoh Kabul (seorang pelaksana proyek jembatan) dan Basar (seorang kades) yang masih mempunyai idealisme kebangsaan. Melalui tokoh ini, pengarang mendambakan perubahan besar bagi tatanan kehidupan berbangsa yang bersih dari penyimpangan dan korupsi.

Sikap hidup pragmatis dari sebagian besar masyarakat Indonesia dewasa ini mengakibatkan 
terkikisnya nilai luhur budaya bangsa. Demikian pula budaya korupsi dan kekerasan sosial turut memperparah kondisi sosial budaya bangsa Indonesia. Nilai kearifan lokal (local wisdom) yang santun, ramah, saling menghormati, arif, dan religius, terutama kejujuran seakan terkikis dan tereduksi oleh gaya hidup instan dan modern.

Masyarakat sangat mudah tersulut emosinya. Muncullah sifat iri hati, vulgar, dan tidak mampu mengendalikan hawa nafsunya. Gejala-gejala tersebut merepresentasikan lemahnya karakter bangsa ini, yang terkenal santun, berpekerti luhur, dan berbudi mulia.

Dengan demikian, melalui Orang-Orang Proyek, secara implisit, sebenarnya kita telah diajak berkontemplasi, merenungkan nilai pendidikan kejiwaan yang seharusnya kita peroleh, tertanam semenjak dini yang berorientasi pada pembentukan karakter tokoh. Tokoh yang berkarakter itu dapat diwujudkan melalui pengoptimalan peran tokoh dalam sastra. Untuk membentuk karakter bangsa ini, sastra diperlakukan sebagai salah satu media atau sarana pendidikan kejiwaan. Hal tersebut cukup beralasan sebab sastra mengandung nilai etika dan moral yang berkaitan dengan hidup dan kehidupan manusia. Sastra tidak hanya berbicara tentang diri sendiri (psikologis), tetapi juga berkaitan dengan Tuhan (religiositas), alam semesta (romantik), dan juga masyarakat (sosiologis). Sastra mampu mengungkap banyak hal dari berbagai segi. Banyak pilihan genre sastra yang dapat dijadikan sarana atau sumber pembentukan karakter bangsa.

Pada bagian kelima, bagian akhir, ditampilkan cerita humor/anekdot (mengkritik) tentang orangorang proyek yang membuat pembaca tertawa atau paling tidak tersenyum. Anekdot yang disampaikan penuh makna. Lewat tokoh Kabul, ia bercerita dengan Wati, istrinya.

Suatu saat di akhirat, penghuni neraka dan penghuni surga ingin saling kunjung. Maka penghuni kedua tempat itu sepakat membuat jembatan yang akan menghubungkan wilayah neraka dan surga. Bagian jembatan di wilayah neraka dibangun oleh orang neraka dan sebaliknya. Ternyata penghuni neraka lebih cepat menyelesaikan pekerjaannya. Dan ketika dicari sebabnya, ditemukan kenyataan di antara para penghuni neraka banyak mantan orang proyek (Tohari, 2007:218).

\section{PENUTUP}

Orang-Orang Proyek adalah sebuah dokumentasi sastra yang cukup menggambarkan suasana. Selain itu, secara cantik, berusaha menghadirkan sebuah realitas kemanusiaan, yakni perlawanan terhadap korupsi dan berbagai penyimpangan. Keterkaitan cerita pada masa kini, sangat dekat. Isu-isu ekonomi, sosial, budaya, dan agama bukan menjadi persoalan yang mesti dicarikan pemecahannya, melainkan menjadi hal yang menguntungkan untuk mendapat simpati rakyat atau sekadar pernyataan-pernyataan heroik. Rakyat pun dininabobokan dengan mimpi yang abstrak. Jeritan rakyat pun dapat ditanggulangi dengan sebuah pernyataan politik (pencitraan) yang menjadi konsumsi publik.

Persoalan pandangan yang baru dianggap benar jika dianut oleh orang banyak memang sepertinya sudah mengakar. Akan tetapi, meskipun ada segelintir orang yang berupaya keras memperjuangkan hak rakyat atas kepemilikan azasinya, mereka selalu terbentur pada tembok kekuatan yang melegitimasi kekuasaan dan kebijakan. Hal ini seperti dialami oleh tokoh Kabul.

Bagi pengarang, karya sastra semacam novel ini, menjadi media alternatif dan sekaligus gerakan kebudayaan untuk tetap konsisten menyuarakan kejujuran dan antikorupsi. Sebuah realitas yang ditirukan dalam sebuah karya sastra, agar memperoleh perhatian dan menjadi akar tindakan bagi kemaslahatan umat.

Orang-Orang Proyek karya Ahmad Tohari menyampaikan kebenaran yang sekaligus juga merupakan kebenaran sejarah dan sosial, semacam sebuah kejeniusan sastra pada zamannya. OrangOrang Proyek tidak hanya mewakili zamannya (saat ditulis dan diterbitkan), tetapi juga mewakili kekinian. Di dalamnya terdapat kebenaran sosial. Karya ini memiliki sebab dan hasil kehebatan nilai artistik sebuah karya sastra (dengan dokumen sosialnya) sebagai potret kenyataan sosial. Inilah yang menjadikan Orang-Orang Proyek sebagai sastra yang bermakna. 
Kurniati : Korupsi yang Menggurita: Tinjauan Sosiologi Sastra Orang-Orang Proyek

\section{DAFTAR PUSTAKA}

Damono, Sapardi Djoko. 1978. Sosiologi Sastra: Sebuah Pengantar Ringkas. Jakarta: Pusat Pembinaan dan Pengembangan Bahasa.

Depdiknas. 2010. Perjalanan Lintas Generasi: dari Marah Rusli ke Dewi Sartika. Jakarta: Depdiknas.

Endraswara, Suwardi. 2008. Metodologi Penelitian Sastra. Jakarta: MedPress.

Mulyani, S. dkk. 1999. Pintar Bahasa dan Sastra Indonesia. Semarang: Aneka Ilmu.

Pradopo, R. D. 2011. Beberapa Teori Sastra, Metode Kritik, dan Penerapannya.Yogyakarta: Pustaka Pelajar.

Pradopo, R.D. 2007. Prinsip-Prinsip Kritik Sastra. Yogyakarta: Gadjah Mada University Press.

Ratna, K.N. 2011. Teori, Metode, dan Teknik Penelitian Sastra. Yogyakarta: Pustaka Pelajar.

Sutrisno, Mudjidan Hendar Putranto. 2005. Teori-Teori Kebudayaan. Yogyakarta: Kanisius.

Thahjono, T. 1988. Sastra Indonesia: Pengantar Teori dan Apresiasi. Ende Flores: Nusa Indah.

Tohari, Ahmad. 2007. Orang-Orang Proyek. Jakarta: Gramedia Pustaka Utama.

Wellek, R. dan Austin W. 1989. Teori Kesusasteraan, terj. Melani Budianta. Jakarta: Gramedia.

Yudiono. 2009. Pengkajian Krikitk Sastra Indonesia. Jakarta: Kompas. 
Kurniati : Korupsi yang Menggurita: Tinjauan Sosiologi Sastra Orang-Orang Proyek 